\title{
MUTUAL EFFECTS OF BIO- AND NATURAL K- FERTILIZATION ON FABA BEAN PLANTS
}

Osman' E. A.M., M.H. Abd El-Aal and G. F. EL-Shiekh

Soils, Water and Environ. Res. Inst., Agric. Res. Center (ARC), Giza, Egypt.

ABSTRACT:

This study was carried out under greenhouse conditions on soil taken from Kalubiya, Governorate, Egypt to study the response of Faba bean plant for bio-fertilizer and with natural sources of potassium fertilization i.e., compost rich in $\mathrm{K}$ content $(\mathrm{CK})$ and $\mathrm{K}$-feldspar (K-bearing mineral, $\left.\mathrm{KAlSi}_{3} \mathrm{O}_{8}\right)(\mathrm{FK})$ compare with Potassium sulfate, $\mathrm{K}_{2} \mathrm{SO}_{4}(\mathrm{MK})$. They were added in a solo or in a mixture forms at rates of half $(1 / 2 \mathrm{KD})$, three-quarter $(3 / 4 \mathrm{KD})$ and full (KD) of the recommended dose (R.D) of potassium (KD = $24 \mathrm{Kg} \mathrm{K}_{2} \mathrm{O} /$ fed.). Faba bean (Vicia faba.L , cv. Giza 843 variety) were inoculated with K-dissolved bacteria Bacillus circulans, (KDB). Yield and contents of $(\mathrm{N}),(\mathrm{P}),(\mathrm{K}),(\mathrm{Fe}),(\mathrm{Mn})$ and $(\mathrm{Zn})$ were studied. The results revealed that inoculation with (KDB) gave the highest seed and straw yields. Moreover, N, P, K, Mn and Zn contents increased as compared with non- inoculation conditions. K-rates significant increased straw, seeds and nutrient contents in compare with non - fertilizer treatment (control). As for the effects of different types of K-sources on seed and straw yields as well as their nutrients content, (MK) was the best treatment followed with (FK) treatment, when both added in a solo form. With respect to the dual mixture $(\mathrm{MK}+\mathrm{FK})$ followed with $(\mathrm{MK}+\mathrm{CK})$ gave the best effects. While, $(\mathrm{FK}+\mathrm{CK})$ and the triple mixture of $(\mathrm{MK}+\mathrm{CK}+\mathrm{FK})$ gave pronounced response on the yield of seed and nutrient's contents.

Key words: Faba bean, potassium fertilizer, Bacillus Circulans, clay soil

\section{INTRODUCTION}

Faba bean (Vicia faba L.) is one of the major leguminous crops grown in the world. It is an important source of protein for humans and animals (El-Gizawy and Mehasen, 2009). Faba bean (Vicia faba L.) is one of the main pulse crops grown for seed in Egypt, due to its high nutritive value, it is a primary source of protein in the diet of masses. Average consumption of dry seeds is estimated at $5.9 \mathrm{~kg} /$ day $/$ person. The fine chopped straw of faba bean is fed to sheep and cattle. The protein content is estimated at 5.5 and $5.9 \%$ for green and dry straw, respectively (Alderfasi and Y.A. Refay, 2010). Potassium is the third macronutrient required for plant growth, after nitrogen and phosphorus. Potassium fertilizers are not subject to leaching or volatilization therefore can be applied to a wide range of environment conditions by different methods of application. $\mathrm{K}$ has an important osmotic role in plants (Fageria, et al., 1991; Tisdale, et al., 1995). Potassium plays a major role in enzyme activation, energy relations, assimilate translocation, protein and starch synthesis (Brag, 1972; Wallingford, 1980).

Since the completion of the High Aswan Dam, the importance of potassium fertilization in Egyptian agriculture is felt after the deposition of Nile mud upstream at the formed lake. The Nile mud is the main source of K-bearing minerals during the seasonal floods. Though, in general, Egyptian soils are rich in potassium content, sporadic responses of several crops to applied K have been reported (Abd El-Hadi $\boldsymbol{e t}$ al., 1990). This is due to the existence of a dynamic equilibrium among the various forms of $\mathrm{K}$ in soil. However, continuous crop removal without replenishment is likely

Fayoum J. Agric. Res. \& Dev., Vol. 27, No.1, January, 2013 
to cause a serious damage from the soil fertility point of view. The reuse of plant residues, rich in $\mathrm{K}$-element, after composting as organic manure (Abdel Moez and Saleh, 1999) solo or mixed with K-bearing minerals (Seddik, 2006) can positively contribute to the supply of a great portion of K-needs. The release of their potassium contents is a part of $\mathrm{K}$-cycle in the soil.

Therefore, this experimental work is conducted to study the response of Faba bean plants grown in clay soil to the addition of some natural $\mathrm{K}$ - sources as well as $\mathrm{K}_{2} \mathrm{SO}_{4}$ fertilizer, which were added solo or in mixtures. Also, inoculations of seeds with $\mathrm{K}$-dissolved bacteria (Bacillus circulans) were tested.

\section{MATERIALS AND METHODS}

Greenhouse experiment was carried out during winter season on a clay soil from, Kalubiya, Governorate, Egypt. Two natural sources of K-fertilizers of:

- Potassium Compost (CK): Natural organic compost rich in K-content supplied by organic manure production unit (Soils, Water and Environment Research Institute, Agric. Res. Center (ARC).

- Feldspar (FK): K-bearing mineral (K-feldspar) $\left(\mathrm{KAlSi}_{3} \mathrm{O}_{8}\right)$, taken from the mines of the Egyptian western desert.

- As well as $\mathrm{K}_{2} \mathrm{SO}_{4}$ mineral $\mathrm{K}$ - fertilizer, $\left(48 \% \mathrm{~K}_{2} \mathrm{O}\right)$.

Some chemical and physical properties of the used soil, K-feldspar and Kcompost were analyzed as according to Page et al., (1982), (Table 1). All used seeds of Faba bean (Vicia Faba. L), cv. Giza 843 were mixed thoroughly with rizobia - sugar solution directly before planting. Then, a half of seed amounts, required for planting half of the experimental pots, were inoculated with potassium dissolving bacteria "Bacillus circulans" (KDB), and denote as control (inoculated with KDB). While the half of seeds, was served without inoculation and denote as (without KDB).

During winter season, on the $5^{\text {th }}$ of November, ten seeds were planted in plastic pots filled with $7 \mathrm{Kg}$, soil, in three replicates. After complete emergence, the seedlings were thinned to four healthy plants in each pot. After one month from planting, all (KDB) inoculated pots received another activation dose from (KDB) added as aqueous solution on the soil surface adjacent to growing plants.

All pots received the basic doses of $\mathrm{N}$ and $\mathrm{P}$ mineral fertilizers equals to 200 $\mathrm{Kg}$-super phosphates per fed. $\left(15.5 \% \mathrm{P}_{2} \mathrm{O}_{5}\right)$ added during pot preparation, and $10-20$ $\mathrm{Kg}$ ammonium sulfate $(20.5 \% \mathrm{~N})$ per fed. in two equal doses, the first dose during seed planting and the other after ten days. Potassium fertilizers were added at these rates; Recommended dose (KD), i.e., $24 \mathrm{Kg}$. $\mathrm{K}_{2} \mathrm{O} /$ fed., three quarter (3/4 KD) and half $(1 / 2 \mathrm{KD})$. The doses of applied $\mathrm{K}$ - fertilizers are approximately equal to the amounts of: $50 \mathrm{Kg} / \mathrm{fed}$. K- Mineral (MK) in the form of potassium sulfate, $\mathrm{K}_{2} \mathrm{SO}_{4}$ $\left(48 \% \mathrm{~K}_{2} \mathrm{O}\right)$ as decided in the bulletins of ministry of agriculture, $500 \mathrm{Kg} / \mathrm{fed} . \mathrm{K}$ Compost, $(\mathrm{CK})\left(4.8 \% \mathrm{~K}_{2} \mathrm{O}\right)$ and $300 \mathrm{Kg} / \mathrm{fed}$. K- Feldspars, (FK) $\left(8.52 \% \mathrm{~K}_{2} \mathrm{O}\right)$.

In the dual mixture treatments, the amounts of $\mathrm{K}$ - fertilizer were added as fifty-fifty from the two used K-sources. While, in the triple mixture K- sources were added as one third from each fertilizer, is used. All the K- rates are added during pot preparation. Then irrigation is carried out, using tap water, and maintained throughout the growing season approximately at field capacity.

All the pots were harvested, after 160 days from planting, separated to straw and seeds, then oven dried. Dry weights of straw and seed of each pot are recorded as $\mathrm{g} / \mathrm{pot}$ and a sample $0.2 \mathrm{~g}$. of dried straw or seed samples are digested using a mixture of $\mathrm{HCIO} 4$ and $\mathrm{H}_{2} \mathrm{SO}_{4}$ acids (Chapman and Pratt, 1961). Then $\mathrm{N}, \mathrm{P}, \mathrm{K}, \mathrm{Fe}, \mathrm{Mn}$ and

Fayoum J. Agric. Res. \& Dev., Vol. 27, No.1, January, 2013 
Zn are determined (Ryan $\boldsymbol{e t}$ al., 1996). Obtained data are statistically, analyzed using the analysis of variance (ANOVA) as a complete randomized factorial design in three factors; with three replicates and least significant differences (LSD) are calculated at levels of 1\% (Barbara and Brain, 1994).

Table 1: Some physical and chemical properties of the used soil and the natural $K$

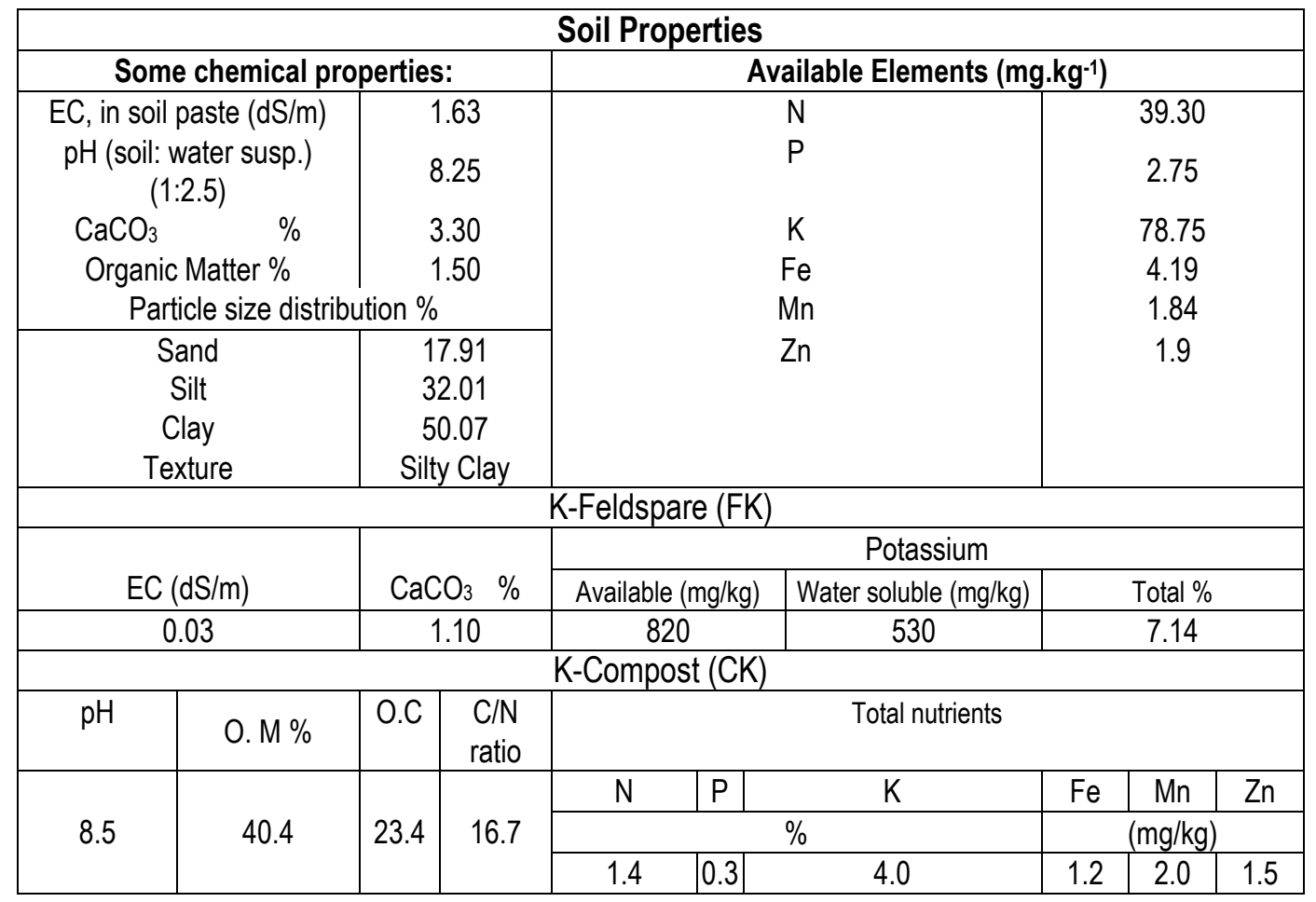

\section{RESULTS AND DISCUSSION \\ Yield Components}

The response of yield components of faba bean plants, expressed as seed and straw yields (g/pot), to inoculation with KDB, fertilization with different sources and rates of potassium were presented in (Table 2). Both of seed and straw yields of faba bean achieved considerable increment due to the inoculation with KDB Bacillus circulans than those non-inoculated. They increased with 36\% (seeds) and $77 \%$ (straw) by the inoculation with Bacillus circulans compared to un-inoculated treatments. These results may be due to the role of inoculation with KDB in stimulating plant growth and to its role in increasing the amount of available- $\mathrm{K}$ in soil (Shady et al.,1983), which in turn will help in solving the problem of insufficient of available $-\mathrm{K}$ in soil through excretion amino acids in the agriculture fields (Mishustin, 1981). Also similar results were obtained by Zahir et al., (1996) who mentioned that inoculation of wheat seed with KDB caused increase in grain yield up to $38.5 \%$ and straw yield up to $18.8 \%$ compared to un-inoculated control and by Abo El- Soud et al., (2004) and Khalil (2005) who reported that using bio-fertilizer of KDB increased number and weight of tubers/fed. of maize.

Due to the effect of K-fertilization sources on faba bean plants, it was noticed that all these sources increased seed and straw yields in comparison with the control

Fayoum J. Agric. Res. \& Dev., Vol. 27, No.1, January, 2013 
treatment. The order of the $\mathrm{K}$-applied can be arranged according to the relative increment, in the descending order of: $\mathrm{MK}>\mathrm{CK}>\mathrm{FK}+\mathrm{CK}>\mathrm{FK}>\mathrm{MK}+\mathrm{C} \mathrm{K}>\mathrm{MK}+\mathrm{FK}$ $>\mathrm{MK}+\mathrm{CK}+\mathrm{FK}$ for seed, while for straw yield the order was: $\mathrm{MK}>\mathrm{FK}>\mathrm{MK}+\mathrm{FK}$ $>\mathrm{MK}+\mathrm{CK}>\mathrm{CK}>\mathrm{FK}+\mathrm{CK}>\mathrm{MK}+\mathrm{FK}+\mathrm{CK}$. The superiority of $\mathrm{K}-$ mineral $(\mathrm{MK}), \mathrm{K}-$ feldspar (FK) or compost $(\mathrm{CK})$ as natural sources for $\mathrm{K}$ fertilization in soil, either added in solo or in a mixture, i.e. $(\mathrm{MK}+\mathrm{FK})$ and $(\mathrm{MK}+\mathrm{CK})$, may be due to the increase of available- $\mathrm{K}$ in these forms than other applied forms and then their addition to soil ensure adequate supply of potassium along the growth season, which led to increase growth yield components and its quality. Similar results were obtained by Shady $\boldsymbol{e t}$ al., (1983) who studied the potassium releasing capacities from siliceous minerals by strains of Bacillus circulans. They found that bacterial inoculation led to a high remarkable increase in the released amount of potassium. Also Basyony et al., (2004) found that a pod yield of peanut and grain as well as the straw yields of wheat were enhanced by the addition of compost combined with mineral, fertilizers which was exhibited high $\mathrm{K}$ availability in soil as compared to mineral fertilizers.

Table 2: Straw and seed yield (g/pot) of Faba bean plant as affected by different sources and rates of $\mathrm{K}$-fertilization and inoculation with (KDB)

\begin{tabular}{|c|c|c|c|c|c|c|c|}
\hline \multirow{3}{*}{\multicolumn{2}{|c|}{ Treatment }} & \multicolumn{3}{|c|}{ Seed yield (g/pot) } & \multicolumn{3}{|c|}{ Straw } \\
\hline & & \multicolumn{6}{|c|}{ K - Fertilization rates, KD } \\
\hline & & $1 / 2$ & $3 / 4$ & KD & $1 / 2$ & $3 / 4$ & KD \\
\hline \multirow{8}{*}{ 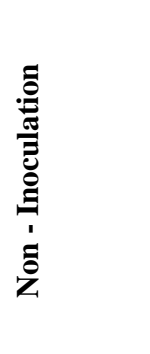 } & Control & 6.00 & 6.00 & 6.00 & 6.50 & 6.50 & 6.50 \\
\hline & Mineral (MK) & 10.20 & 11.50 & 12.20 & 15.33 & 15.40 & 15.90 \\
\hline & Compost(CK) & 9.46 & 10.20 & 10.60 & 11.13 & 11.40 & 11.70 \\
\hline & Feldspar (FK) & 8.53 & 9.49 & 10.00 & 12.88 & 15.20 & 13.30 \\
\hline & $\mathrm{MK}+\mathrm{CK}$ & 8.16 & 9.37 & 9.72 & 10.48 & 10.50 & 11.70 \\
\hline & MK+FK & 8.36 & 9.69 & 10.02 & 12.06 & 12.61 & 16.96 \\
\hline & $\mathbf{F K}+\mathrm{CK}$ & 7.53 & 7.89 & 8.29 & 11.91 & 12.88 & 12.96 \\
\hline & MK+FK+CK & 7.03 & 7.62 & 8.02 & 12.77 & 12.88 & 13.24 \\
\hline \multirow{8}{*}{ 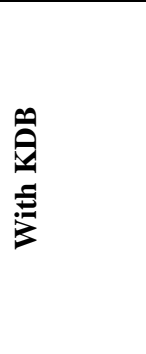 } & Control & 7.40 & 7.40 & 7.40 & 10.06 & 10.06 & 10.06 \\
\hline & Mineral (MK) & 13.63 & 14.26 & 14.53 & 25.10 & 29.33 & 31.33 \\
\hline & Compost(CK) & 11.30 & 11.69 & 12.16 & 19.06 & 22.13 & 26.66 \\
\hline & Feldspar (FK) & 11.93 & 12.13 & 12.98 & 18.10 & 24.10 & 29.33 \\
\hline & $\mathrm{MK}+\mathrm{CK}$ & 12.13 & 12.46 & 13.02 & 18.03 & 25.10 & 29.00 \\
\hline & MK+FK & 11.66 & 11.93 & 12.20 & 19.10 & 23.13 & 27.66 \\
\hline & FK+CK & 13.63 & 13.96 & 13.99 & 17.13 & 19.13 & 22.32 \\
\hline & $\mathrm{MK}+\mathrm{FK}+\mathrm{CK}$ & 11.63 & 12.76 & 12.93 & 16.16 & 18.20 & 21.18 \\
\hline \multirow{4}{*}{ L.S.D.0.01 } & Bacteria (B) & \multicolumn{3}{|c|}{0.07} & \multicolumn{3}{|c|}{0.29} \\
\hline & Sources (S) & \multicolumn{3}{|c|}{0.19} & \multicolumn{3}{|c|}{0.80} \\
\hline & Rates (R) & \multicolumn{3}{|c|}{0.33} & \multicolumn{3}{|c|}{1.39} \\
\hline & BxSxR & \multicolumn{3}{|c|}{0.40} & \multicolumn{3}{|c|}{1.66} \\
\hline
\end{tabular}

Data, also, declared that increasing the level of K- fertilizers, over the control treatment, increased the seed and straw yields of broad bean. On the other side, the lowest increments are achieved in seed and straw yields with $1 / 2 \% \mathrm{KD}$ While the highest increment values were recorded with $\mathrm{KD}$ and $3 / 4 \mathrm{KD}$ with non-significant difference between them. The average values of yield were 9.91, 10.53 and 10.89 $\mathrm{g} /$ pot. for seed and 14.74, 16.80 and $18.50 \mathrm{~g} /$ pot. for straw at the rates of $1 / 2 \mathrm{KD}, 3 / 4$ $\mathrm{KD}$ and $\mathrm{KD}$, respectively. This may be due to enough potassium supply that increases

Fayoum J. Agric. Res. \& Dev., Vol. 27, No.1, January, 2013 
yield and improves the quality of most crops by stimulating chlorophyll synthesis and many vital physiological processes in the plant (Fadl, 2006).Similar results were obtained by Kurdali et al., (2002) who studied the impact of three rates of potassium fertilizer on broad bean, and found that the high rate of K- fertilizer increased the dry matter production.

Generally, increasing trend of seed and straw yields is more pronounced under inoculation with KDB (Bacillus circulans) in combination with (MK) then (MK+FK) and $(\mathrm{CK})$ sources without obvious significant differences between 3/4 KD and KD Similar results were obtained by Khalil (2005) who reported that inoculation with potassium dissolving bacteria (Bacillus circulans) combined with mineral fertilizer or compost addition, affected positively the straw yield of broad bean.

\section{N, P and K-contents:}

Table (3) presents N, P and K contents (mg) of seed and straw of faba bean as affected by inoculation with KDB and addation of potassium fertilization. Inoculation with KDB increased significantly N, P and K contents of seed and straw as compared with non-inoculation. The mean values of macro-nutrient contents of seed were 415.61, 47.68 and $126.74 \mathrm{mg}$ under inoculation with KDB compared with the corresponding values of $280.7,32.05$ and $49.66 \mathrm{mg}$ of un- inoculated treatments for $\mathrm{N}, \mathrm{K}$ and $\mathrm{P}$, respectively. Also, mean contents of macro-nutrients of straw treatments inoculated with KDB are 519.65, $22.22 \mathrm{mg}$. and 237.02 while un-inoculated ones are $166.00,8.00$ and $85.23 \mathrm{mg}$ for $\mathrm{N}, \mathrm{P}$ and $\mathrm{K}$, respectively. Rossi (1990) verified the role of microorganisms of silicate bacteria in mobilization of potassium from nonavailable sources, through degradation of alumina-silicate mineral; this role produces equilibrium between the various potassium fractions in soil, and then insures of enough supply of potassium in soil and increases K-uptake by plants along the growing season. As well as, his explanation for other indirect friendly relationships between soil and bio-fertilizers includes KDB, led to the enrichment of the nutrients quantity and quality in soil. On the other hand, (Khalil, 2005 and Ebtsam et al., 2006) described the role of KDB (Bacillus Circulans) in increasing the N-uptake by plants. Leinhos and Vadek (1994) showed the role of bacteria in solubilizing of insoluble- $\mathrm{K}$ in the soil.

In general, the highest values of $\mathrm{N}, \mathrm{P}$ and $\mathrm{K}$-contents ( $\mathrm{mg} / \mathrm{plant})$ of seed and straw of faba bean are recorded with (MK) treatment is compared to the control treatment, which recorded the lowest values. The effect of K-fertilization type on $\mathrm{N}$ contents of seed and straw, reveled that the highest values are noticed with the treatments of $(\mathrm{MK}),(\mathrm{CK}),(\mathrm{MK}+\mathrm{CK})$ and $(\mathrm{MK}+\mathrm{FK})$ with non-significant differences between any of them. Few experiments are recorded, such as seed $\mathrm{N}$ content in high $\mathrm{KD}$ treatments of $(\mathrm{M}+\mathrm{F}+\mathrm{C})$. Besides $\mathrm{N}$ content of straw of high $\mathrm{RD}$ potassium fertilizers treatments, while $\mathrm{N}$ content of seed and straw in the treatments of $(\mathrm{FK})$ and $(\mathrm{FK}+\mathrm{CK})$ are lower than $\mathrm{N}$ contents of the aforementioned treatments.

The superiority of P-content (mg/ pot) of seed and straw is obvious with the treatments of $(\mathrm{MK}),(\mathrm{CK}),(\mathrm{MK}+\mathrm{CK})$ and $(\mathrm{MK}+\mathrm{FK}+\mathrm{CK})$, followed by the treatments of $(\mathrm{FK}),(\mathrm{FK}+\mathrm{CK})$ and $(\mathrm{MK}+\mathrm{FK})$ with slight differences between the values of the same group.

The descending order of $\mathrm{K}$-content $(\mathrm{mg})$ of seed was $\mathrm{MK}(125.46)>\mathrm{M}+\mathrm{F}$ (101.89) > F (100.12) > MK+CK (89.81) >MK +FK+ CK (89.00) >CK (88.62) > FK+CK (88.09) >control (22.60). But the descending order of K-content (mg) of straw was MK (279.17) > FK (207.69) > CK (195.33)> MK + CK (175.59) > MK+ $\mathrm{FK}(172.07)>\mathrm{MK}+\mathrm{FK}+\mathrm{CK}(128.26)$ and $\mathrm{FK}+\mathrm{CK}$ (122.38). The present results were in agreement with those achieved by El-Shikha et al., (2005) who found that $\mathrm{N}$

Fayoum J. Agric. Res. \& Dev., Vol. 27, No.1, January, 2013 
Osman' E. A.M., et al.

uptake $\mathrm{K}$ content and protein content in seeds and straw of faba bean increased significantly with K-fertilization. Also, Ismail and Hagag (2005) found that, potassium application usually increases the Faba bean yield and improves P- uptake.

Table 3: $N$, $P$ and $K$ contents $(\mathrm{mg})$ of Seed and Straw of faba bean plants as affected by inoculation with (KDB) sources and rates of potassium fertilization

\begin{tabular}{|c|c|c|c|c|c|c|c|c|c|c|c|c|c|}
\hline \multirow{4}{*}{ } & \multirow{4}{*}{$\underset{\mathscr{E}}{\stackrel{\mathscr{\Xi}}{\approx}}$} & \multicolumn{12}{|c|}{ Nutrients Contents (mg/ pot) } \\
\hline & & \multicolumn{6}{|c|}{ Seeds } & \multicolumn{6}{|c|}{ Straw } \\
\hline & & \multicolumn{2}{|c|}{$\mathbf{N}$} & \multicolumn{2}{|c|}{$\mathbf{P}$} & \multicolumn{2}{|c|}{$\mathbf{K}$} & \multicolumn{2}{|c|}{$\mathbf{N}$} & \multicolumn{2}{|c|}{$\mathbf{P}$} & \multicolumn{2}{|c|}{$\mathbf{K}$} \\
\hline & & Without & $\begin{array}{l}\text { With } \\
\text { KDB }\end{array}$ & Without & $\begin{array}{l}\text { With } \\
\text { KDB }\end{array}$ & Without & $\begin{array}{l}\text { With } \\
\text { KDB }\end{array}$ & Without & $\begin{array}{l}\text { With } \\
\text { KDB }\end{array}$ & Without & $\begin{array}{l}\text { With } \\
\text { KDB }\end{array}$ & Without & $\begin{array}{l}\text { With } \\
\text { KDB }\end{array}$ \\
\hline Control & \multirow{8}{*}{$\begin{array}{l}\hat{\theta} \\
\underline{\Sigma}\end{array}$} & 115.3 & 194.0 & 15.9 & 21.1 & 15.6 & 29.6 & 75.8 & 118.1 & 2.6 & 4.0 & 5.9 & 11.1 \\
\hline Mineral (MK) & & 432.5 & 667.1 & 52.4 & 47.7 & 63.5 & 169.0 & 234.0 & 609.9 & 7.7 & 20.1 & 136.5 & 351.4 \\
\hline Compost(CK) & & 357.0 & 483.3 & 36.7 & 46.3 & 50.2 & 115.2 & 143.2 & 596.1 & 7.8 & 19.1 & 70.1 & 247.9 \\
\hline Feldspar (FK) & & 185.3 & 266.5 & 23.7 & 35.4 & 49.5 & 136.0 & 147.3 & 281.7 & 6.4 & 14.5 & 92.8 & 233.5 \\
\hline MK+CK & & 275.3 & 402.4 & 31.5 & 77.5 & 45.0 & 116.4 & 166.2 & 599.9 & 8.4 & 18.0 & 79.7 & 162.3 \\
\hline MK+FK & & 252.8 & 386.6 & 25.6 & 39.1 & 50.2 & 140.0 & 174.1 & 546.9 & 6.0 & 15.3 & 94.1 & 168.1 \\
\hline FK+CK & & 208.7 & 397.7 & 25.9 & 47.0 & 40.7 & 125.4 & 158.0 & 246.1 & 6.0 & 13.7 & 76.3 & 135.4 \\
\hline $\mathrm{MK}+\mathrm{FK}+\mathrm{CK}$ & & 219.5 & 381.2 & 25.2 & 52.3 & 39.4 & 123.0 & 182.2 & 424.6 & 9.0 & 16.2 & 95.8 & 132.6 \\
\hline Control & \multirow{8}{*}{$\frac{\theta}{\frac{1}{m}}$} & 115.3 & 194.0 & 15.9 & 21.1 & 15.6 & 29.6 & 75.83 & 118.1 & 2.6 & 4.0 & 5.9 & 11.1 \\
\hline Mineral (MK) & & 490.5 & 702.8 & 58.9 & 48.6 & 73.9 & 179.7 & 239.7 & 711.8 & 9.3 & 26.4 & 141.0 & 428.2 \\
\hline Compost(CK) & & 390.1 & 506.0 & 40.0 & 49.1 & 56.5 & 127.5 & 148.6 & 696.4 & 9.1 & 26.6 & 73.2 & 309.8 \\
\hline Feldspar (FK) & & 207.8 & 277.4 & 27.5 & 36.4 & 56.0 & 140.7 & 147.7 & 379.9 & 7.8 & 21.7 & 94.6 & 320.5 \\
\hline MK+CK & & 318.8 & 418.4 & 35.6 & 81.0 & 53.4 & 123.4 & 169.5 & 842.5 & 9.5 & 32.6 & 81.3 & 276.1 \\
\hline MK+FK & & 299.4 & 399.2 & 30.0 & 41.8 & 60.1 & 145.4 & 186.2 & 671.6 & 7.6 & 20.8 & 99.6 & 205.8 \\
\hline FK+CK & & 221.0 & 410.0 & 27.6 & 50.3 & 43.4 & 132.3 & 172.1 & 278.7 & 7.7 & 19.1 & 83.7 & 158.8 \\
\hline $\mathrm{MK}+\mathrm{FK}+\mathrm{CK}$ & & 240.0 & 420.7 & 27.4 & 54.9 & 43.4 & 139.1 & 191.1 & 487.1 & 10.3 & 27.3 & 97.9 & 154.9 \\
\hline Control & \multirow{8}{*}{$\theta$} & 115.3 & 194.0 & 15.9 & 21.1 & 15.6 & 29.6 & 75.8 & 118.1 & 2.6 & 4.0 & 5.9 & 11.1 \\
\hline Mineral (MK) & & 525.0 & 718.9 & 59.5 & 51.1 & 80.6 & 186.0 & 246.4 & 766.6 & 11.1 & 31.3 & 147.8 & 470.0 \\
\hline Compost(CK) & & 411.3 & 530.0 & 41.9 & 51.0 & 62.0 & 120.4 & 157.3 & 844.4 & 10.6 & 34.7 & 76.5 & 394.4 \\
\hline Feldspar (FK) & & 222.3 & 331.5 & 28.3 & 40.6 & 61.4 & 157.1 & 154.6 & 468.3 & 9.3 & 32.3 & 100.0 & 404.8 \\
\hline MK+CK & & 331.5 & 439.8 & 35.6 & 87.3 & 57.4 & 143.3 & 190.2 & 830.5 & 10.6 & 40.6 & 91.8 & 362.5 \\
\hline MK+FK & & 310.8 & 411.1 & 30.2 & 42.7 & 63.2 & 152.4 & 196.2 & 876.3 & 9.1 & 30.4 & 105.0 & 359.6 \\
\hline FK+CK & & 236.4 & 413.7 & 28.8 & 52.4 & 48.1 & 138.5 & 174.5 & 349.8 & 9.1 & 26.8 & 88.2 & 192.0 \\
\hline $\mathrm{MK}+\mathrm{FK}+\mathrm{CK}$ & & 254.4 & 727.5 & 29.0 & 54.5 & 47.4 & 141.7 & 188.9 & 607.2 & 11.9 & 33.9 & 102.0 & 186.3 \\
\hline \multicolumn{14}{|c|}{ L.S.D.0.01 } \\
\hline Bacteria (B) & & \multicolumn{2}{|c|}{4.59} & \multicolumn{2}{|c|}{0.97} & \multicolumn{2}{|c|}{0.60} & \multicolumn{2}{|c|}{18.62} & \multicolumn{2}{|c|}{0.01} & \multicolumn{2}{|c|}{1.97} \\
\hline Sources (S) & & \multicolumn{2}{|c|}{12.49} & \multicolumn{2}{|c|}{2.65} & \multicolumn{2}{|c|}{1.61} & \multicolumn{2}{|c|}{50.60} & 0.5 & & 5. & \\
\hline Rates (R) & & 21. & & 4.6 & & 2.8 & & 87. & & 0.9 & & 9. & \\
\hline BxSxR & & 26. & & 5.5 & & 3.3 & & 10 & & 1.0 & & 11. & \\
\hline
\end{tabular}

Data also reveal that $\mathrm{N}, \mathrm{P}$ and K-contents $(\mathrm{mg})$ of faba bean seed and straw significantly increased with increasing the rate of $\mathrm{K}$-fertilization, the increase percentages in $\mathrm{N}$ - content of seed are $111.26 \%, 126.06 \%$ and $137.46 \%$ while, they are $203.14 \%, 255.50 \%$ and $302.43 \%$, for straw at the rates of potassium fertilizers of $1 / 2$ $\mathrm{KD}, 3 / 4 \mathrm{KD}$ and $\mathrm{KD}$, respectively. The percentage increases in P-content of seed were $103.6 \%, 118.2 \%$ and $124.0 \%$ and they were $229 \%, 357 \%$ and $480.5 \%$ for straw at $\mathrm{K}$ - rates of $1 / 2 \mathrm{KD}, 3 / 4 \mathrm{KD}$ and $\mathrm{KD}$, respectively. While the percentages increases in $\mathrm{K}$-content $\mathrm{K}$-fertilizers at rates of $1 / 2 \mathrm{KD}, 3 / 4 \mathrm{KD}$ and $\mathrm{KD}$ are $262 \%, 293 \%$ and $316 \%$ for seed and they are $1442 \%, 1774 \%$ and $2183 \%$ for straw. These results are in

Fayoum J. Agric. Res. \& Dev., Vol. 27, No.1, January, 2013 
agreement with those obtained by El-Sawah et al. (1985) who found that the contents of N, P and $\mathrm{K}$ for Faba bean plants increased with increasing the rate of $\mathrm{K}$-fertilizer addition.

Table 4: $\mathrm{Fe}$, Mn and $\mathrm{Zn}$ contents (mg/pot) of Seed and Straw of faba bean plants as affected by inoculation with (KDB) sources and rates of potassium fertilization

\begin{tabular}{|c|c|c|c|c|c|c|c|c|c|c|c|c|c|}
\hline \multirow{4}{*}{ 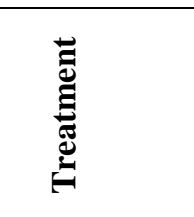 } & \multirow{4}{*}{$\underset{\mathscr{E}}{\stackrel{2}{\pi}}$} & \multicolumn{12}{|c|}{ Nutrients Contents (mg/ pot) } \\
\hline & & \multirow{2}{*}{\multicolumn{2}{|c|}{$\mathbf{e}$}} & \multicolumn{4}{|c|}{ Seeds } & \multicolumn{6}{|c|}{ Straw } \\
\hline & & & & Mi & & $\mathrm{Zn}$ & & $\mathbf{F e}$ & & $\mathrm{Mr}$ & & $\mathrm{Zn}$ & \\
\hline & & Without & $\begin{array}{l}\text { With } \\
\text { KDB }\end{array}$ & Without & $\begin{array}{l}\text { With } \\
\text { KDB }\end{array}$ & Without & $\begin{array}{l}\text { With } \\
\text { KDB }\end{array}$ & Without & $\begin{array}{l}\text { With } \\
\text { KDB }\end{array}$ & Without & $\begin{array}{l}\text { With } \\
\text { KDB }\end{array}$ & Without & $\begin{array}{l}\text { With } \\
\text { KDB }\end{array}$ \\
\hline Control & \multirow{8}{*}{$\frac{1}{2}$} & 0.01 & 0.90 & 1.89 & 0.56 & 2.12 & 0.61 & 1.83 & 31.03 & 29.39 & 16.36 & 26.20 & 24.13 \\
\hline Mineral (MK) & & 1.65 & 1.69 & 0.52 & 3.27 & 3.27 & 2.38 & 26.52 & 20.18 & 4.50 & 54.21 & 53.19 & 25.70 \\
\hline \begin{tabular}{|c|}
$\operatorname{Compost}(\mathrm{CK})$ \\
\end{tabular} & & 6.06 & 1.86 & 6.27 & 2.79 & 0.05 & 0.21 & 46.88 & 41.63 & 40.43 & 29.10 & 0.12 & 1.32 \\
\hline Feldspar (FK) & & 0.57 & 0.17 & 0.38 & 0.14 & 0.14 & 0.10 & 1.07 & 0.67 & 0.92 & 0.55 & 0.98 & 1.10 \\
\hline MK+CK & & 0.13 & 0.50 & 1.04 & 0.36 & 0.71 & 0.31 & 0.40 & 2.21 & 2.61 & 1.19 & 1.84 & 1.10 \\
\hline MK+FK & & 0.42 & 0.29 & 0.10 & 0.39 & 0.39 & 0.31 & 1.64 & 1.58 & 1.04 & 2.78 & 3.12 & 2.31 \\
\hline FK+CK & & 0.28 & 0.27 & 0.27 & 0.26 & 0.15 & 0.63 & 2.09 & 2.22 & 2.62 & 3.06 & 1.92 & 5.52 \\
\hline MK+FK+ & & 0.59 & 0.50 & 0.49 & 0.45 & 0.60 & 0.56 & 6.86 & 3.58 & 5.05 & 3.78 & 4.45 & 4.36 \\
\hline Control & \multirow{8}{*}{$\frac{\theta}{\dot{y}}$} & 0.01 & 1.06 & 2.46 & 0.68 & 2.62 & 0.76 & 1.89 & 1.98 & 0.52 & 3.71 & 3.34 & 2.91 \\
\hline Mineral (MK) & & 6.48 & 2.17 & 6.56 & 3.34 & 0.05 & 0.28 & 0.69 & 0.21 & 0.46 & 0.17 & 0.16 & 0.14 \\
\hline \begin{tabular}{|c|}
$\operatorname{Compost}(\mathrm{CK})$ \\
\end{tabular} & & 0.13 & 0.59 & 1.18 & 0.47 & 0.75 & 0.34 & 0.45 & 0.36 & 0.10 & 0.46 & 0.45 & 0.36 \\
\hline Feldspar (FK) & & 0.33 & 0.33 & 0.30 & 0.30 & 0.15 & 0.69 & 0.64 & 0.54 & 0.53 & 0.48 & 0.65 & 0.64 \\
\hline MK+CK & & 1.83 & 31.47 & 30.87 & 16.59 & 26.70 & 25.57 & 28.72 & 20.61 & 4.50 & 63.94 & 61.97 & 36.15 \\
\hline MK+FK & & 67.77 & 51.35 & 45.73 & 34.21 & 0.12 & 1.40 & 1.14 & 0.73 & 0.97 & 0.63 & 1.11 & 1.13 \\
\hline FK+CK & & 0.40 & 2.69 & 3.22 & 1.68 & 2.66 & 1.48 & 1.91 & 1.86 & 1.04 & 2.85 & 3.43 & 2.36 \\
\hline MK+FK+CK & & 2.65 & 2.37 & 3.09 & 3.35 & 1.92 & 7.04 & 8.41 & 5.30 & 7.33 & 6.01 & .08 & 5.02 \\
\hline Control & \multirow{8}{*}{$\theta$} & 0.01 & 1.24 & 2.80 & 0.78 & 2.91 & 0.82 & 2.07 & 2.12 & 0.52 & 3.86 & 3.53 & 3.25 \\
\hline Mineral (MK) & & 6.82 & 2.34 & 6.76 & 3.41 & 0.05 & 0.35 & 0.88 & 0.27 & 0.51 & 0.20 & 0.22 & 0.18 \\
\hline Compost(CK) & & 0.13 & 0.67 & 1.32 & 0.55 & 0.84 & 0.40 & 0.47 & 0.39 & 0.10 & 0.51 & 0.51 & 0.40 \\
\hline Feldspar (FK) & & 0.37 & 0.36 & 0.34 & 0.37 & 0.15 & 0.76 & 0.72 & 0.60 & 0.58 & 0.52 & 0.68 & 0.67 \\
\hline MK+CK & & 1.83 & 32.15 & 32.15 & 17.60 & 30.24 & 27.23 & 29.01 & 22.25 & 4.50 & 69.56 & 76.26 & 26.98 \\
\hline MK+FK & & 67.28 & 62.52 & 53.58 & 41.51 & 0.12 & 1.53 & 1.20 & 0.80 & 1.15 & 0.70 & 1.14 & 1.22 \\
\hline FK+CK & & 0.40 & 3.36 & 3.57 & 1.64 & 3.13 & 1.82 & 2.27 & 1.20 & 1.04 & 2.86 & 3.64 & 2.53 \\
\hline $\mathrm{MK}+\mathrm{FK}+\mathrm{CK}$ & & 3.06 & 2.49 & 3.26 & 3.51 & 1.92 & 8.14 & 10.6 & 7.04 & 8.76 & 7.24 & 6.02 & 5.89 \\
\hline \multicolumn{14}{|c|}{ L.S.D.0.01 } \\
\hline Bacteria (B) & & \multicolumn{2}{|c|}{2.24} & \multicolumn{2}{|c|}{2.53} & \multicolumn{2}{|c|}{2.71} & \multicolumn{2}{|c|}{0.10} & \multicolumn{2}{|c|}{0.34} & \multicolumn{2}{|c|}{0.40} \\
\hline Sources (S) & & \multicolumn{2}{|c|}{0.46} & \multicolumn{2}{|c|}{0.08} & \multicolumn{2}{|c|}{0.02} & \multicolumn{2}{|c|}{0.01} & \multicolumn{2}{|c|}{0.02} & \multicolumn{2}{|c|}{0.02} \\
\hline Rates (R) & & \multicolumn{2}{|c|}{29.45} & \multicolumn{2}{|c|}{30.43} & \multicolumn{2}{|c|}{34.25} & \multicolumn{2}{|c|}{0.63} & 1.2 & & 1.4 & \\
\hline BxSxR & & 1.6 & & 0.0 & & 0.0 & & 0.1 & & 0.2 & & 0.3 & \\
\hline
\end{tabular}

\section{Fe, Mn and Zn-contents}

Data in Table (4) indicate that the values of Fe, Mn and $\mathrm{Zn}$-contents $\mathrm{mg} / \mathrm{pot}$ of seed and straw of Faba bean increase significantly as a result of inoculation with KDB Their contents in seed are 3.58, 0.53 and $0.54 \mathrm{mg}$ and in straw are 44.31, 1.95 and $5.72 \mathrm{mg}$ for $\mathrm{Fe}, \mathrm{Mn}$ and $\mathrm{Zn}$ respectively, due to the inoculation with KDB While the corresponding values that recorded by un- inoculated treatments for seeds are $1.41,0.27$ and $0.32 \mathrm{mg}$ and for straw are 22.94, 0.91 and $2.62 \mathrm{mg}$ for Fe, $\mathrm{Mn}$ and $\mathrm{Zn}$, respectively. These results are in accordance with Khalil (2005) who reported that inoculation with (Bacillus circulans) affected significantly Fe, Mn and $\mathrm{Zn}$ uptake of

Fayoum J. Agric. Res. \& Dev., Vol. 27, No.1, January, 2013 
broad bean, peanut and wheat. This increase may be due to the mechanisms of these microbes (Bacillus circulans) that dissolve non-soluble nutrients, hence improving their availability to the plants. Also Rabie et al. (1995) and Neeru et al. (2000) supported these findings.

With respect to the role of K-fertilizer type, generally it is be noticed that treated soil with $(\mathrm{CK}),(\mathrm{MK})$ or $(\mathrm{MK}+\mathrm{CK})$ showed the highest $\mathrm{Fe}, \mathrm{Mn}$ and $\mathrm{Zn}$ contents, while their lowest contents are recorded with the treatments of $(\mathrm{MK}+\mathrm{FK}),(\mathrm{FK})$ or $(\mathrm{MK}+\mathrm{FK}+\mathrm{CK})$ either for seed or straw. These results are in agreement with those achieved by Abdel Moez and Salah (1999), El Shikha et al. (2005) and Kahlil (2005).

Due to the role of increasing rate of potassium fertilizers on contents of $\mathrm{Fe}$, $\mathrm{Mn}$ and $\mathrm{Zn}$-contents of seed and straw of faba bean plants. They were significantly affected by increasing the application rates of $\mathrm{K}$ - fertilizers. Fe- content of seed increased from 0.31 to 2.71 (mg/pot), while Fe-content of straw increased gradually from 3.16 to 34.25 (mg/ pot) with increasing the rate of K- fertilizers from (Zero KD) to full KD. Also, increasing the rate of K- fertilizers from control (Zero KD) to full KD increased Mn-content of seed from 0.09 to $0.46 \mathrm{mg}$ and from 0.26 to 1.64 for seed and straw, respectively. On the other hand, increasing application rates of Kfertilizers from control (Zero KD) to full KD increased Zn-content of seed from 0.12 to $0.47 \mathrm{mg} /$ pot and from 1.48 to $4.88 \mathrm{mg} /$ pot for seed and straw respectively.

\section{CONCLUSION}

Faba bean (Vicia faba L.) is one of the main pulse crops grown for seed in Egypt, and it is ably to inoculation with bacteria to give higher seed and straw yields. Moreover, mineral fertilizer $(\mathrm{MK})$ followed $(\mathrm{FK})$ treatment and the dual mixture of $(\mathrm{MK}+\mathrm{FK})$ followed with $(\mathrm{MK}+\mathrm{CK})$ gave the best effects on the yield of seed and nutrient's contents.

\section{REFERENCES}

Abd EI-Hady, A.H., M.S. Khadr and M.A.M. Hassan 1990. Effect of fertilization on the productivity of Lahor field crops under intensive cropping system in Egypt. 3rd International Congress Program of Soil Science Society of Pakistan, March 20-22.

Abdel Moez, M.R. and A.L. Saleh, 1999. Effect of organic fertilizers application on growth, yield and mineral uptake of Roselle- plants as compared to chemical fertilizer. J. Agric.Sci., Mansoura Univ., 24 (6): 3157- 3170.

Abo El-Soud, A.A., M.A. El-Deeb and Kh.M. El-Yamani, 2004. Improving of faba bean production by application of organic compost and Rhizobial inoculation under newly reclaimed sandy soil. Egypt J. Appl. Sci., 19 (5): 333-344.

Alderfasi, A.A. and Y.A. Refay, 2010. Integrated Use of Potassium Fertilizer and Water Schedules on Growth and Yield of Two Wheat Genotypes under Arid Environment in Saudi Arabia 1- Effect on Growth Characters. AmericanEurasian J. Agric. \& Environ. Sci., 9 (3): 239-247.

Barbara , F.R. and L.J.,Brain 1994. Minitab Hand book. Duxbury press. An Imprint of Wad Sworth Publish . Comp. Belonont California U.S.A.

Basyouny, El. A., Sh. M. Gawish and S.S. Behairy, 2004. Response of plants grown on sandy soil to organic and mineral fertilization. Egypt. J. Appl. Sci., 19 (3):375-387.

Brag, H., 1972. The influence of potassium on the transpiration rate and stomatal opening in Triticum aestivum and Pisum sativum. Plant Physiol., 26: 250-255.

Fayoum J. Agric. Res. \& Dev., Vol. 27, No.1, January, 2013 
Chapman, H.D. and P.E. Pratt, 1961. Methods for analysis for soils, plants and waters. Univ. of Calif, Div. of Agric. Science.

Ebtsam, M.M, A.A. Mahmoud and A.A. Khalil, 2006. Influence of bio inoculation and various potassium application rates on soil fertility, maize productivity and yield components. Egypt. Appl. Sci., 21 (7): 255-267.

El-Gizawy, N.K.B. and S.A.S. Mehasen, 2009. Response of faba bean to bio, mineral phosphorus fertilizers and foliar application with zinc. Journal World Applied Sciences, 6 (10): 1359-1365.

El-Sawah, M.H., M.R.. Gabel, A.A. Gad and A.M. Metawlly, 1985. Effect of P and $\mathrm{K}$ fertilizer levels on growth, mineral composition, yield and its components of broad bean. Zagazig. Journal Agric. Res., 12 (2): 88-114.

EI-Shikha, S.A., M.O. Easa, S.K. Behiry and M.I. Resian, 2005. Effect of Kfertilization faba bean productivity under sandy soil condition. Egypt J. Appl. Sci., 20 (1): 335-344.

Fadl, M.N.A., 2006. Effect of some agricultural treatments on productivity of some faba bean genotypes at Middle Egypt location. Ph.D. Thesis, Fac. of Agric, , Al-Azhar Univ., Egypt.

Fageria, N.K., V.C. Baligar and C.A. Jones, 1991. Wheat and Barley: Growth and Mineral Nutrition of Field Crops. Marcel Dekker, New York. Pages 125-158.

Ismail, K.M. and A.A., Hagag, 2005. Response of faba bean yield (Visia faba L.) to phosphorus and potassium under different methods of application in sandy soils. J. Agric. Sci. Mansoura Univ., 30 (2): 1249-1258.

Khalil , M.H., 2005. Efficiency of bio-fertilization under some problems of soils. Ph.D. Thesis, Fac. of Agric., Al-Azhar Univ., Egypt.

Kurdali, F., F. Al-Ain and M. Al-Shamma, 2002. Nodulation, dry matter production, and N2 fixation by faba bean and chickpea as affected by soil moisture and potassium fertilizer. J. Plant Nutrition. 25 (2): 355- 368.

Leinhos, V. and O. Vadek, 1994. Biosynthesis of auxins by phosphate solubilizing rhizobacteria from wheat (Triticum aestivum) and rye (Secale cereale). Microbiol. Res., 149: 31-35.

Mishustin, E.N., G.A. Smirnova and R.A. Lakhmacheve, 1981. Destruction of silicates by microorganisms and the application of silicate bacteria as bacterial fertilizers .IZV.Aked Nauk SSSR ser Biol., 5,698-708.

Neeru N., K. Vivek, K.B. Rishi, D. Annette, G. Andreas and M. Wolfgang, 2000. Effect of P-solubilizing Azotobacter chroococcum on N,p,K uptake in P- responsive wheat genotypes grown under greenhouse conditions J. Plant Nutr. Soil Sci., 163: 393-398.

Page, A.L., R.H. Miller and D.R. Keeney, 1982. Methods of soil analysis Part 2. Chemical and microbiological properties. Second Edition. Amer Soc. Of Agron .Madison, Wisconsin, USA .

Rabie, M.H., A.M. El-Saadani, M.F. Abdel-Sabour and I.A.I. Mousa, 1995. The use of water hyacinth (Eichhornia crassipes) as an organic manure to amend soils. Egypt. J. Soil Sci., 35(1): 105-116.

Rossi,G., 1990. Mechanisms of microbial action . Biohydrometallurgy Mc. Graw Hill book company Gmth, hamburg, pp. 97-105\&516-520.

Ryan, J., S. Garabet, K. Harmsen and A .Rashid, 1996. A soil and plant Analysis Manual Adapted for the west Asia and North Africa Region. ICARDA , Aleppo , Syria . 140pp.

Fayoum J. Agric. Res. \& Dev., Vol. 27, No.1, January, 2013 
Seddik, M.A., 2006. Effect of organic manures and feldspar application on some sandy soil physical and chemical properties and their reflection on peanut productivity. J. Agric., Sci. Mansoura Univ., 31 (10): 6675-6687.

Shady, M.A., I. Ibrahim and H. Aaida, 1983. Microbial mobilization of potassium from primary minerals .in the proc. of 1st Conf.Agric Botony Sci., Mansoura Univ., Mansoura, Egypt, pp. 27-28. Thompson, B. (2004) Efu Manual potassium. http.www.back-tobasics. net/efu/pdfs/potassium. pdf.

Tisdale, S.L., W.L. Nelson and J.D. Beaton, 1995. Elements Required in Plant Nutrition. Soil Fertility and Fertilizers, pp: 59-94.

Wallingford, W., 1980. Function of potassium in plants in: Potassium for Agriculture. Potash and Phosphate Inst. Atlanta, Georgia. . pp: 10-27.

Zahir, Z.A., A. Mohammad, H. Altaf., M. Arshad and A. Hussain, 1996. Response of wheat (triticum aestivum) to Azotobacter inoculation under fertilized conditions. Sarhad. J. Agric., 12 (2): 249-256.

$$
\begin{aligned}
& \text { التأثيرات المتبادلة للتسميد الحيوى والتسميد بمصادر طبيعية للبوتاسيوم على نباتات الفول البلاى التي }
\end{aligned}
$$

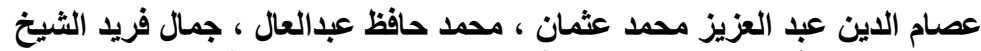

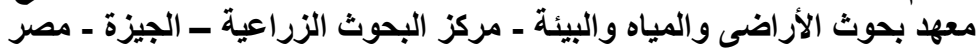

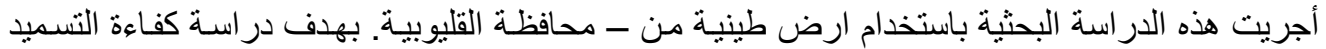

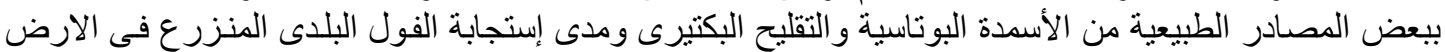

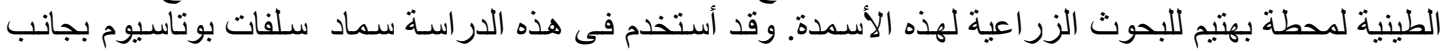

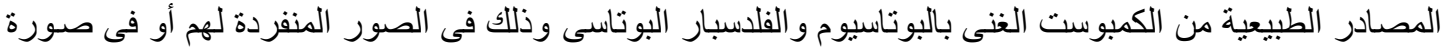

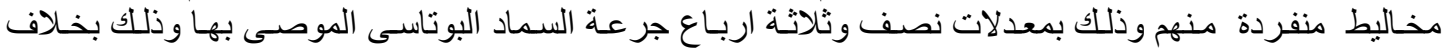

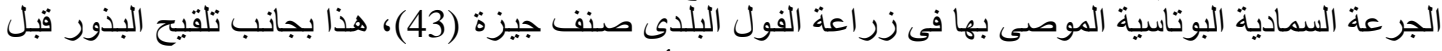

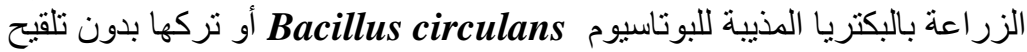

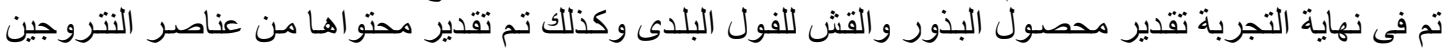

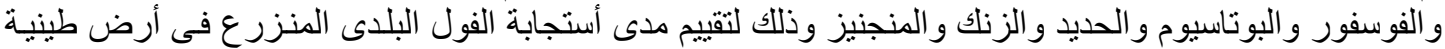

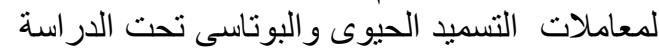
وكاتت أهم النتائج :

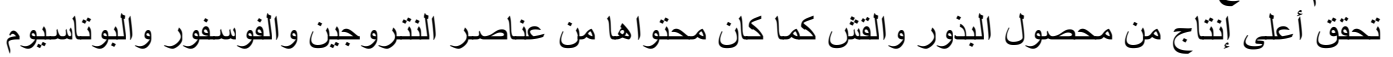

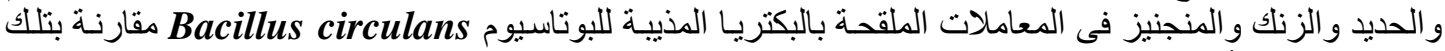

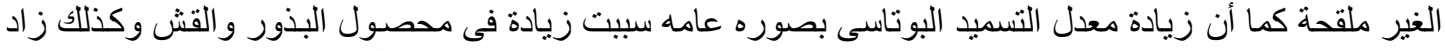

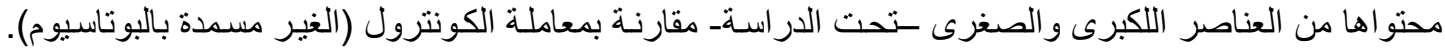

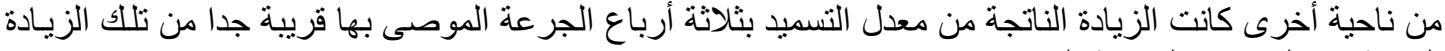

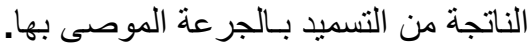

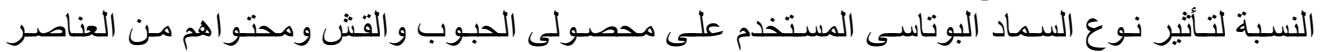

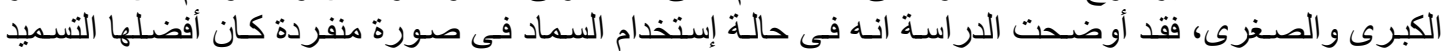

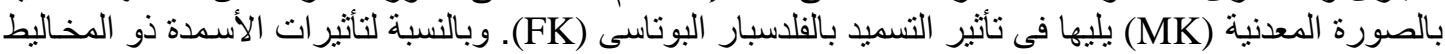

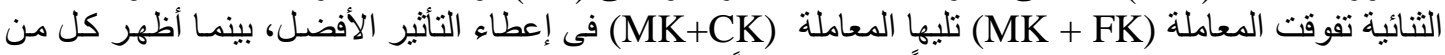

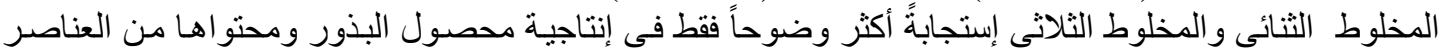

